\title{
PHENOMENOLOGY AND HERMENEUTICS OF REVELATION. TWO-VOICE OF PAUL RICOEUR AND JEAN-LUC MARION
}

\author{
PhD. Piotr KARPIŃSKI, \\ Pontifical Faculty of Theology in Warsaw \\ Higher Seminary in Łowicz, \\ POLAND, \\ Email: piotrkar@o2.pl
}

\begin{abstract}
Revelation is a key category for both phenomenology and hermeneutics. The first domain deals with the possibility of revelation, while the second through its interpretation seeks to understand the reality. Hermeneutics of Paul Ricoeur is characterized by a focus on understanding the human ipseity (soi) and as such refers to phenomenology. Ricoeur is the author of the term 'hermeneutic phenomenology'. Initially, he emphasized the separation between the revelation of the sacrum and the verbal message of religious traditions. With time, however, he noticed that the religious word assumes the functions of numinosum, becoming a place of revelation. After all, Ricoeur remains on the content side of revelation, and therefore the phenomenology of Jean-Luc Marion, who treats revelation from a purely phenomenological point of view, is a valuable complement to this research. Revelation is the giving of the phenomenon as such, on its own initiative, starting from itself, independent from the subject, saturated phenomenon. From this two-voice of Ricoeur and Marion emerges a full picture of the philosophy of revelation, confirming at the same time the need for cooperation between phenomenology and hermeneutics.
\end{abstract}

Keywords: hermeneutics; Marion; phenomenology; revelation; Ricoeur;

\section{INTRODUCTION}

The reader familiar with the hermeneutic tradition certainly met with G. Scholtz's famous distinction between technical hermeneutics, philosophical hermeneutics and hermeneutic philosophy ${ }^{1}$. It allows us to organize the history of interpretation art and theory, which has an ancient origin. The first of the distinguished forms was a technique of interpreting texts highlighted and recognized as canonical, the second one was a study of reality that can be understood, the third is finally a form of philosophy in which the phenomenon of understanding not only becomes the center of analysis, but is referred to key philosophical issues. Representatives of hermeneutic philosophy include such philosophers as W. Dilthey, M. Heidegger, H.-G. Gadamer as well as P. Ricoeur. And although they represent quite different philosophical positions, it is assumed that hermeneutic philosophy is the most mature form of hermeneutic thought ${ }^{2}$.

\footnotetext{
${ }^{1}$ Günther Scholz, "Was ist und seit wann gibt es »hermeneutische Philosophie«?”, in Dilthey-Jahrbuch für Philosophie und Geschichte der Geisteswissenschaften Vol. 8 (1993), pp. 93-119.

2 Graeme Nicholson, "Hermenutical Phenomenology", in L. Embree (ed.), Encyclopedia of Phenomenology, Kluwer Academic Publishers, Dordrecht, 1997, p. 305.
} 
It seems, however, that the unconditional inclusion of Ricoeur in the current of hermeneutic philosophy is too hasty ${ }^{3}$. And it certainly does not accurately reflect the originality of the thoughts of the French philosopher, who does not yield to easy classifications. Ricoeur is the author of the interesting term 'hermeneutic phenomenology', which is not found in either Heidegger or Gadamer. When criticizing Husserl's phenomenology, he emphasized that hermeneutics only undermines a certain idealistic version of phenomenology, not it itself. Ricoeur is close to phenomenology from the period of Husserl's The Logical Investigations, ${ }^{5}$, which combines hermeneutics with a senseorientation. The very expression 'hermeneutic phenomenology' gives rise to the thought. It seems that both areas need each other: phenomenology emphasizes that the noematic constitution is ahead of the linguistic order, while hermeneutics draws attention to prepredicative experiences in the world of life. Hence, hermeneutic phenomenology is research that attempts to reveal the structures of human understanding of reality, i.e. phenomena in the phenomenological sense, by understanding the study of phenomena in the common sense. Ricoeur calls this a long way of human self-knowledge through the analysis of cultures ${ }^{6}$. In turn, in it, a huge role is played by religious and symbolic texts, the interpretation of which is the hallmark of Ricoeur? ${ }^{7}$.

In this paper we want to extract and analyze the category of revelation, which is essential for both phenomenology and hermeneutics of the self. After all, a phenomenon is what appears or reveals, and understanding is achieved most fully through religious or revealed texts. In Ricoeur's rich writing there is an interesting text Manifestation et proclamation from the volume Le Sacré. Etudes et recherches ${ }^{8}$, in which he takes up this issue. It seems, however, that it is dominated by an object-oriented and substantive perspective - Ricoeur asks a lot more about 'what' is manifesting than 'how' it is manifesting. Therefore, we want to collate Ricoeur's research with the phenomenology of the revelation of J.-L. Marion, who in turn is interested not so much in the content of the revelation, but in the mere its possibility. Ricoeur approaches the revelation from the hermeneutic side and explores the phenomenon in a common sense, while Marion looks phenomenologically, treating the phenomenon not as 'what' of appearing, but merely

\footnotetext{
${ }^{3}$ Ricoeur's thought is more polyphonic. In Lectio magistralis he distinguishes in his biography three periods related to different ways of practicing philosophy. In the first period he was strongly influenced by phenomenology (Philosophie de la volonté. Tome 1. Le volontaire et l'involontaire), in the second he made a hermeneutic turn (Philosophie de la volonté. Tome 2. Finitude et culpabilité; De l'interprétation. Essai sur Freud; Le conflit des interprétations: Essais d'herméneutique; La métaphore vive; Temps et récit. Tome 1-3; Du texte à l'action. Essais d'herméneutique II), to finally work out synthetic and dialectical vision of human (Soimême comme un autre). See Jean Grondin, Paul Ricoeur, PUF, Paris, 2013, p. 21. Bernard Stevens, "En guise d'introduction: L'évolution de la pensée de Ricoeur au fil de son explication avec Husserl", in Études phénoménologiques 11 (1990), pp. 9-27.

${ }^{4}$ Paul Ricoeur, Du texte à l'action. Essais d'herméneutique II. Jean Grondin, Paul Ricoeur, pp. 44-45. Françoise Dastur, "De la phénoménologie transcendentale à la phénoménologie herméneutique", in J. Greisch and R. Kearney (eds.), Paul Ricoeur. Les metamorphoses de la raison herméneutique. Actes du colloque de Cerisy-la-Salle, 1-11 août 1988, Cerf, Paris, 1991, pp. 37-50.

${ }^{5}$ Edmund Husserl, Logische Untersuchungen, Bd. 1-2, Max Niemeyer Verlag, Halle, 1913.

${ }^{6}$ Philippe Huneman, Estelle Kulich, Introduction à la phénoménologie, Armand Colin, Paris, 1997, p. 168.

${ }^{7}$ Paul Ricoeur, Le conflit des interprétations: Essais d'herméneutique, p. 169.

${ }^{8}$ Paul Ricoeur, "Manifestation et proclamation", in E. Castelli (ed.), Le sacré: études et recherches. Actes du $14^{e}$ Colloque international sur la thématique de la démythisation, Rome, 4-9 janvier 1974, organisé par le Centre international d'études humanistes et par l'Institut d'études philosophiques de Rome, Aubier, Paris, 1974, pp. 57-76.
} 
revealing itself. We will therefore follow the philosophy of the revelation of both authors in the hope that this two-voice will not only illuminate the revelation from two sides, but also shed interesting light on the relationship between phenomenology and hermeneutics.

\section{REVELATION IN THEOLOGY, PHENOMENOLOGY AND HERMENEUTICS}

Revelation is a fundamental category for theology, phenomenology and hermeneutics. The first of these domains wants to explore, explain and systematize revealed truths, but because they relate to God, or His actions in the world and towards human as a supernatural reality, they cannot be given in a natural order. As M. Scheler noticed, all knowledge about God is knowledge through $\operatorname{God}^{9}$, so theological knowledge implies God's revelation to man. Revelation is the exposure or enlightenment that God makes in His relationship with human. Theology does not ask, however, how it is done cognitively, but emphasizes the content and historical dimension of revelation. Revelation in theology is therefore divine-human, it is associated with the creation and salvation of man. There are various models of the revelation in theology: it can be understood as doctrine, as history, as internal experience, as a new human consciousness, and finally as the dialectical presence of God in the reality of the world. However, the compilation of these models clearly shows which aspect of revelation lies within the interests of theology.

Phenomenology presents a completely different approach to revelation. First of all, it should be noted that the revelation is found in the name of the method itself - the name 'phenomenology' comes not so much from the Greek noun phainomenon, 'what appears', but from the verb phainesthai, 'to appear ${ }^{10}$. Phenomenology should not deal with phenomena themselves, but rather their appearance. It should investigate how something becomes a phenomenon, that is, appearing, showing itself, revealing itself, discovering itself - in short, revealing something, coming into the condition of the phenomenon ${ }^{11}$.

It can be said that while theology treats revelation in terms of effectiveness, phenomenology does it in terms of possibility ${ }^{12}$. For theology, revelation is a collection of truths about God that reaches beyond human cognitive capabilities. It is often understood as a collection of holy books, whose authorship, at least indirectly, is attributed to God. Theological revelation therefore implies divine authority, and the acceptance of which requires faith. An example of the theological approach to revelation is the definition of the Second Vatican Council, which was included in the Dogmatic Constitution on Divine Revelation Dei Verbum: 'In His goodness and wisdom God chose to reveal Himself and to make known to us the hidden purpose of His will (see Eph. 1:9) by which through Christ, the Word made flesh, man might in the Holy Spirit have access to the Father and come to share in the divine nature (see Eph. 2:18; 2 Peter 1:4). Through this revelation, therefore, the invisible God (see Col. 1;15, 1 Tim. 1:17) out of the abundance of His love speaks to men as friends (see Ex. 33:11; John 15:14-15) and lives among them (see Bar. 3:38), so that He may invite and take them into fellowship with Himself' (Dei Verbum, p. 2) ${ }^{13}$. Meanwhile,

\footnotetext{
${ }^{9}$ Max Scheler, Vom Ewigen in Menschen, Francke Verlag, Bern-München, 1954, p. 248.

${ }^{10}$ Martin Heidegger, Sein und Zeit, Niemeyer, Tübingen, 1960, p. 47.

${ }^{11}$ Michel Henry, Incarnation. Une philosophie de la chaire, Seuil, Paris, 2000, p. 35.

${ }^{12}$ Stéphane Vinolo, Dieu n'a que faire de l'être. Introduction à l'œuvre de Jean-Luc Marion, Germina, Paris, 2012, p. 115. Jean-Luc Marion, La rigueur des choses. Entretiens avec Dan Arbib, Flammarion, Paris, 2012, p. 296.

${ }^{13}$ Dei Verbum. Dogmatic Constitution on Divine Revelation of the Second Vatican Council, in http://www.vatican.va/archive/hist_councils/ii_vatican_council/documents/vatii_const_19651118_deiverbum_en.html [10.06.2020].
} 
phenomenology does not ask about sacred texts, about the content of revelation, about words and deeds, but about the very possibility of revelation. We could ask in Kantian way how the subject must be built so that anything could appear to it? Or, what is the revelation, this coming into the condition of a phenomenon? What is revelation as a pure possibility?

Finally, the hermeneutics also deals with revelation, or more precisely revelation needs a certain hermeneutics, since it is a system of signs, gestures, and also has a linguistic dimension. Revelation is, on the one hand, a manifestation of sacrum, a hierophany, and on the other, it helps man understand better himself. Writing about revelation, P. Tillich speaks of an event that 'seized the human spirit' and in which 'the ultimate is present in ultimate care, accompanied by a shock and transformation of the situation prevailing in religion and culture" ${ }^{14}$. According to M. Buber, the revelation is that 'we receive what we have not had before, and we receive it in such a way that we know that it was given to us ${ }^{, 15}$. And although revelation is the receptive correlate of faith, it also modifies the understanding of the human subject of this relationship. Man, through revelation, can understand that he is known, wanted, gifted, judged, that he will always be secondary and passive before God. This perspective is closest to Ricoeur. He undertakes the content of revelation to lead to an understanding of the self, especially of such existencials as culpability, human failure, will or the possibility of evil ${ }^{16}$. Unlike 'masters of suspicion', Ricoeur develops the hermeneutics of reconstruction, according to which revealed texts not only hide important truths about human life, but also reveal life in its fullness ${ }^{17}$. In this sense, revelation does not so much bring what was previously unknown, but allows man to find himself in the reality in which he lives. Hermeneutics of revelation is therefore a relationship between symbolic speech and selfunderstanding.

In our research, we skip the theological perspective, and focus on phenomenology and hermeneutics of revelation. First, we'll look at what content Ricoeur extracts from religious texts. This content approach will then be completed with formal elements of Marion's possibility of revelation.

\section{RICOEUR: FROM PHENOMENOLOGY OF REVELATION TO HERMENEUTICS OF PROCLAMATION}

It is indeed surprising that Ricoeur does not apply the concept of 'revelation' to religious traditions related to the word, especially to the Judeo-Christian tradition. He makes an interesting distinction between revelation and proclamation ${ }^{18}$. The first is more connected with the phenomenology of the sacum, and the second with the hermeneutics of religious speech.

What is the revelation of the sacrum? Ricoeur follows the research of such phenomenologists of religion as M. Eliade or R. Otto and he treats revelation as the selfpresentation of the deity, i.e. hierophany ${ }^{19}$. As he writes: 'a hierophany is everything that

\footnotetext{
${ }^{14}$ Paul Tilich, Dynamics of faith, Harper \& Row, New York, 1957, pp. 78-79.

${ }^{15}$ Martin Buber, I and Thou, Scribner, New York, 1958, pp. 109-110.

${ }^{16}$ Paul Ricoeur, Philosophie de la volonté. Tome 2. Finitude et culpabilité, Aubier, Paris, 1960, pp. 26-28.

${ }^{17}$ Alison Scott-Baumann, Ricoeur and the Hermeneutics of Suspicion, Continuum, London-New York, 2009, p. 175.

${ }^{18}$ Paul Ricoeur, Manifestation et proclamation, p. 57.

19 Halina Romanowska-Łakomy, Our Sacred Dimension. The Sanctity of the Common Man, Cambridge Scholars Publishing, Cambridge, 2016, p. 153.
} 
shows the sacrum ${ }^{20}$. It is important, however, that revelation has nothing verbal, rather it consists in appearance, and therefore has a close relationship with the primary and natural religions, and not with the religions of the word as Judaism, Christianity and Islam.

Ricoeur lists five features of the sacrum revelation that show how the revelation is anti-hermeneutic. Firstly, the sacrum is the power and strength and as such does not fit in with the logic of logos, proclamation, communication and interpretation. In revelation, we have precedence of strength over sense, and power and word are mutually exclusive. Secondly, revelation has the form, structure and articulation, but it does not grant any privilege to the word, but is temporal-spatial and even aesthetic. Sacrum can manifest itself in a stone, a tree or on the mountain, and worship is given to it not by means of words, but by an appropriate ritual. As $\mathrm{H}$. Corbin puts it, the sacrum extends into the space of revelation, which should be called imaginary, rather than being logos ${ }^{21}$. Thirdly, the revelation of the sacrum has to do with the rite, which enhances its non-linguistic nature. The rite is not a word but a way of acting, it requires specific behavior and something to be done with power. Of course, the word can be an element of the rite, e.g. in the form of myths, but it will always be an dependent or even incomprehensible element without a rite. Fourthly, in the revelation of the sacrum, natural elements play an important role - it is the sacred power of nature, the symbol of the tree of life, the image of the Mother-Earth, the vegetative cults, the natural symbols, etc. Finally, the world of the sacrum is governed by a special logic of sense. What is it about? Ricoeur defines it as the 'law of correspondence' ${ }^{22}$ : elements from the sacred sphere correspond to elements from the human sphere, the macrocosm finds its counterpart in the microcosm, e.g. the relationship between man and woman reflects the hierogamy of heaven and earth.

Revelation is therefore non-verbal, non-dialogical and in some sense non-logical. The sacrum reveals itself but says nothing. The revelation of the sacrum opens up some possibility of enunciation, but not vice versa, i.e. no expression has the power to reveal the sacrum. As Ricoeur writes: 'All these qualities testify to the fact that in the sacred world the ability to speak (something) is grounded in the capacity of meaning (something) possessed by the Cosmos ${ }^{, 23}$.

Something completely different from revelation is proclamation, which belongs to religious traditions related to the word. To see this difference, Ricoeur postulates the distinction between sacrum and religion. The Hebrew environment not only carried a verbal message, but even undertook the fight against the sacred world, as exemplified by the struggle of the prophets of Israel against Canaanite cults, vegetation and agricultural myths, against all natural and cosmic sacrum. However, the relationship between revelation and the word is not just an exclusion relationship, but an absorption relationship, as Ricoeur claims: 'the word absorbs the entire numinosum, ${ }^{24}$. Numinosum appears in the Bible or Koran, but only as the background on which the word resounds. To show this dominant word, Ricoeur accepts for G. von Rad that all theology of Israel is organized around certain basic forms of expression, such as story, Torah regulations, prophecies, hymns, wisdoms, etc. ${ }^{25}$. In Hebrew

\footnotetext{
${ }^{20}$ Paul Ricoeur, Manifestation et proclamation, p. 59. All translations in this paper by Piotr Karpiński, unless otherwise noted.

${ }^{21}$ Henry Corbin, L'imagination creatrice dans le soufisme d'Ibn 'Arabi, Flammarion, Paris, 1961.

${ }^{22}$ Paul Ricoeur, Manifestation et proclamation, p. 63.

${ }^{23}$ Ibidem.

${ }^{24}$ Ibidem, p. 64.

${ }^{25}$ Gerhard von Rad, Theologie des Alten Testaments, Kaiser Verlag, Munich, 1957.
} 
culture, the revelation as a hierophany begins to disappear as far as the Torah texts begin to dominate the image, and watching the signs is replaced by listening to the word. The sacrality of nature in the Hebrew world disappears completely in the face of the word and historical element.

Most importantly, according to Ricoeur, revelation and proclamation are ruled by different logics. While the first was ruled by the law of correspondence, in the second it was completely eradicated. Not only is there no correspondence between the microcosm and the macrocosm, but to enter the path of true religiosity and accept God's word message, one must even break with his world, as can be seen in the call: 'Follow me' (see Lk 9, 59). Therefore, the religion of the word is not governed by the logic of correspondence but by the logic of 'boundary expressions' ${ }^{26}$. Such a boundary expression is the term 'Kingdom of God' from the Bible parables. As a result of the systematic use of hyperbole, a kind of intensification of the text occurs, which leads to paradoxes, and finally the text begins to carry a certain existential call. Boundary expressions disrupt ordinary speech. While the world of the sacrum was internally tied, the world of parables, proverbs, speeches is a disintegrated world. Is it threatened with some chaos? No. According to Ricoeur, it is falling apart towards the Kingdom of God - it is exceeding the world towards a new quality. Therefore, it is not about disintegration but transcending the present world which is passing away.

Ricoeur concludes that religious speech uses the boundary expressions to open our experience and push it toward the boundary experiences. These are not only crisis and decision-making moments, as in K. Jaspers ${ }^{27}$, but above all are the culmination moments, as in the parable of the precious pearl, where finding something most precious evokes the greatest joy (Mt 13, 44). If we suspended for a while the distinction between revelation and proclamation and treated the revelation in general, including the tradition of the sacred word, we see that it has an extremely existential character in Ricoeur. The word reveals, appeals, calls, notifies, but above all activates man in the direction of finding the most authentic existence. But how is revelation possible? How is human built that he can be the recipient of both revelation and proclamation? To get the answer to these questions, we'll turn to Marion's phenomenology.

\section{MARION: REVELATION AS A POSSIBILITY OF PHENOMENON}

Marion's thought follows three paths that inspire and penetrate each other: Cartesianism, theology and phenomenology ${ }^{28}$. At the same time, it is extremely antimetaphysical $^{29}$. He also constantly strives to broaden the field of phenomenality so that it is possible to think of invisible phenomena, e.g. religious phenomena. In this last project, the category of revelation plays a key role. In most texts about revelation, Marion raises the question of the philosophy of religion and the possibility of its extension in the form of the phenomenology of religion. However, the most important for Marion is the discovery in the

\footnotetext{
${ }^{26}$ Paul Ricoeur, Manifestation et proclamation, p. 66.

27 Karl Jaspers, Allgemeine Psychopathologie, Springer, Berlin-Heidelberg, 1946, p. 271. Karl Jaspers, Psychologie der Weltaschaungen, Springer, Berlin-Heidelberg-New York, 1971, p. 229.

${ }_{28}$ Marion's most important Cartesian works: Sur l'ontologie grise de Descartes (1975); Sur la théologie blanche de Descartes (1981); Sur le prisme métaphysique de Descartes (1986). Marion's most important theological works: L'Idole et la distance (1977); Dieu sans l'être (1982); Prolégomènes à la charité (1986). Marion's most important phenomenological works: Réduction et donation (1989); Étant donné (1997); De surcroît (2001).

${ }^{29}$ Jean-Luc Marion, "La « fin de la métaphysique » comme possibilité", in Y.-Ch. Zarka and B. Pinchard (eds.), Y a-t-il une histoire de la métaphysique?, PUF, Paris, 2005, pp. 343-368.
} 
revelation of the phenomenon's independence, especially from the subject, and in this sense it is a highly anti-transcendental thought.

Already in the first phenomenological work Réduction et donation the question what the phenomenology is dominates and what does it mean to practice $\mathrm{it}^{30}$. The author argues in it with both Husserl and Heidegger, whose phenomenological principles did not allow achieving the maximum degree of phenomenality. Phenomenological reductions stopped somewhat in the middle of the way - Husserl reduced phenomena to the sphere of objectivity $^{31}$, while Heidegger to the sphere of being ${ }^{32}$. Thus, the phenomenon did not have the features of revelation, but was dependent on the subject and its constitutive consciousness. In the next work Étant donné Marion formulates his fundamental phenomenological principle: 'so much reduction, so much givenness' (Autant de réduction, autant de donation $)^{33}$. Marion is looking for a phenomenon that would be unconditioned, would not depend on anything or anyone, but would come by itself and present itself as such. In this way, the phenomenon will be able to take the form of revelation, which consists of appearing as it is, starting from itself and on its own initiative.

To let the phenomenon appear freely, one should look at its structure, which has a dual character. It's about the correlation between such pairs as: intuition-intention, meaningfulfillment, noema-noesis. Any phenomenality is realized in these two terms. There is a correlation between what appears and what corresponds from the subject side. On the one hand, visibility (intuition), on the other hand, the intentional attitude of consciousness and the concept that visibility fills. But thanks to such understanding of the phenomenon, we can indicate different degrees of givenness. Husserl practically saw only one possibility - when visibility perfectly matches the intention. Marion, in turn, shows that this is not the only solution possible. He first distinguishes phenomena poor in intuition, e.g. objects of mathematics or logic ${ }^{34}$. The second type are the common-law phenomena in which the meaning or intentional attitude is revealed as far as it receives fulfillment in visibility ${ }^{35}$. This category includes physical objects, objects of nature, as well as technical objects. What couples both categories of phenomena is the primacy of the concept over visibility, and therefore the lack of givenness. This is why they remain poor in phenomenality, because they only appear as objects. Marion calls it diminutio phenomenalitatis, decreased phenomenality $^{36}$. However, should all phenomenality be reduced to these two types only? Is there no other figure that is not characterized by adequacy, but rather an inadequacy between visibility and the concept? In other words, can one understand the field of phenomenality beyond the object and requirements of formal and logical categories? This necessity gives birth to the idea of the saturated phenomenon, which Marion also calls the paradox ${ }^{37}$.

In the saturated phenomenon, any compatibility, adequacy between visibility and concept is erased. The intuition is so intense that it surprises and saturates any concept. The saturated phenomenon has an event structure rather than an object and cannot be predicted or

\footnotetext{
${ }^{30}$ Jean-Luc Marion, Réduction et donation. Recherches sur Husserl, Heidegger et la phénoménologie, PUF, Paris, 1989 , p. 7.

${ }^{31}$ Jean-Luc Marion, Étant donné. Essai d’une phénoménologie de la donation, PUF, Paris, 1997, p. 52.

${ }^{32}$ Ibidem, p. 57.

${ }^{33}$ Jean-Luc Marion, Réduction et donation, p. 303. Jean-Luc Marion, Étant donné, p. 23.

${ }^{34}$ Jean-Luc Marion, Étant donné, p. 365.

${ }^{35}$ Ibidem, p. 366.

${ }^{36}$ Pascal Tabet, Amour et donation chez Jean-Luc Marion. Une phénoménologie de l'excès, L'Harmattan, Paris, 2017 , p. 84.

37 Jean-Luc Marion, Étant donné, p. 370-373.
} 
planned. Incoming from somewhere else intuition can only be accepted. Of course, the concept of 'saturation' is not new, in the history of philosophy its glimpses appeared, such as the light in the Platonic allegory of the cave, the idea of infinity in Descartes, or the experience of beauty in Kant. However, it was Marion who fully developed the concept of the saturated phenomenon. In the ordinary object constitution, the concept is primary - it enables the synthesis of visibility into an objective sense. Meanwhile, according to Marion, such visibility is possible, which is not preceded by any intention or meaning. What's more, any concept is missing to synthesize it. The visibility transcends the concept, so that the concept no longer constitutes it, and it does not appear as an object, but has the character of an event. This situation is just a saturated phenomenon. It is not constituted by the transcendental ' $I$ ', it is not an object at all. The saturated phenomenon brings a different reality for description of which there is no concept in the subject. Therefore, in order to receive the saturated phenomenon, the subject can no longer be pure consciousness, transcendental ego, or even Dasein, but must find itself within the givenness structure as the recipient $-l^{\prime}$ adonné $e^{38}$.

By the concept of the saturated phenomenon, Marion wanted to introduce into the horizon of consciousness the non-appearing phenomena (l'inapparent), and thus extend the limits of phenomenology to all areas of human life. How can we explain the cognition of such phenomena as religion, which transcend the sphere of visibility? Religion is a phenomenon that philosophy excludes. Determine under what conditions this phenomenon is definable or not - this is the challenge that Marion takes on the issue of saturated phenomena.

Marion distinguishes four types of saturated phenomena: the event, the idol, the corporeality and the icon ${ }^{39}$. The event is unpredictable, emerges without a reason known in advance, without any supposition, it is impossible to determine by the moment, place or experience of the individual ${ }^{40}$. In turn, the idol or work of art imposes on the regard such a level of visibility that it fills it to such an extent that it can no longer deal with the transformation of visibility into an object and no longer experiences this visibility without synthesis as an object spectacle, but as the state of the subject experiencing something, which it is not able to synthesize ${ }^{41}$. The third type of saturated phenomenon is the own body, which consists in experiencing itself first before being able to experience something else ${ }^{42}$. Finally, the icon is a phenomenon that is unobservable and cannot be constituted into object within a finite phenomenological field. What is visible in the full sense of the word in the other's face or icon, which, facing me, looks at me, not allowing me to look at it. The icon is what provides nothing to the gaze and which, being inaccessible to the viewer, nevertheless keeps its gaze on it. The icon is the other's gaze on the ' $\mathrm{I}$ '43.

Thus, we see that the saturated phenomenon appears by itself and starting from itself, from its own ipseity. Marion defines this independent phenomenon as revelation. As he writes in the article Le phénomène saturé from 1992: 'The saturated phenomenon, because it gives itself without conditions or restraint, offers the of the phenomenon without reservation. Thus, in the thread of the saturated phenomenon, phenomenology finds its last possibility: not only the possibility which surpasses effectiveness, but the possibility which surpasses the

\footnotetext{
${ }^{38}$ Ibidem, p. 405.

39 Ibidem, p. 373.

${ }^{40}$ Ibidem, p. 374-376.

${ }^{41}$ Ibidem, p. 376-378.

${ }^{42}$ Ibidem, p. 378-380.

${ }^{43}$ Ibidem, p. 380-383.
} 
very conditions of possibility, the possibility of unconditioned possibility - otherwise says the possibility of the impossible, the saturated phenomenon'44. And further: 'The saturated phenomenon should not be understood as a unique, exceptional, vaguely irrational, not to say mystic, case of phenomenality. On the contrary, it marks the coherent and conceptual fulfillment of the most operational definition of the phenomenon: it alone appears truly as itself, from itself and starting from himself, since it alone appears without the limits of a horizon nor reduction to an "I". We will also name this appearance purely from itself, which does not subject its possibility to any prior determination, a revelation ${ }^{45}$. Only the saturated phenomenon meets the requirements of revelation, because, as Marion writes, 'by revelation we mean here a strictly phenomenological concept: a purely appearing from itself and starting from itself ${ }^{46}$.

In the aforementioned article Le phénomène saturé from 1992, as well as in the work De surcroit from 2001, Marion classifies saturated phenomena in such a way that the revelation together with the icon belongs to the last type of saturated phenomena. However, in the work Étant donné from 1997 he treats revelation separately as a possibility of a saturated phenomenon par excellence, which includes all other figures of saturation. Revelation is then the fifth degree of saturation - saturation of the saturation.

The fact caused numerous polemical voices, among others from D. Janicaud ${ }^{47}$ and $\mathrm{J}$. Benoist $^{48}$. They accused Marion of the famous 'theological turn' in phenomenology. Marion states: '(...) with the question of a phenomenon bringing saturation to its maximum, it is not (...) a debate on the status of theology in phenomenology, but (...) of a possible figure of the phenomenality as such,49. Marion's goal is neither to practice theology within phenomenology, nor to make theology out of phenomenology, but to free the possibilities in phenomenality. In other words, releasing the phenomenon from all its limitations, such as objectivity (Husserl), beingness (Heidegger), but also from compliance with the common principles (metaphysics), or poverty in visibility. To this end, however, it is necessary to restore certain concepts that are reserved for theology, and in particular the concept of 'revelation'. It should be remembered, as mentioned above, that Marion treats revelation as a possibility (possibilité) and not as effectivity (effectivité) - the last aspect, i.e. the study of the ontological status of revelation, its effective accomplishment and content, belongs to theology. Marion considers revelation in immanence reduced to givenness. Phenomenology, therefore, describes the phenomenon of revelation as the possibility of phenomenality, the possibility of appearing itself. It never speaks about the reality, historicity or content of revelation in a given religious tradition. It is easy to distinguish in Marion's texts - revelation in the phenomenological sense is written in the lowercase, while in the theological sense it is written in capital letter. Therefore, it is not about phenomenology evidence that God has revealed to human, but only about rethinking whether such revelation is possible, and if so, how it corresponds to the characteristics of the saturated phenomenon. Phenomenology is not able to decide whether revelation ever took place, but if it ever happened, it must be done

\footnotetext{
${ }^{44}$ Jean-Luc Marion, "Le phénomène saturé", in J.-F. Courtine (ed.), Phénoménologie et Théologie, Criterion, Paris, 1992, p. 123.

${ }^{45}$ Ibidem, p. 123-124.

${ }^{46}$ Ibidem, p. 127.

47 Dominique Janicaud, Le tournant théologique de la phénoménologie française, Éditions de l'éclat, Combas, 1991.

${ }^{48}$ Jocelyn Benoist, L'idée de la phénoménologie, Beauchesne, Paris, 2001.

${ }^{49}$ Jean-Luc Marion, Étant donné, p. 384.
} 
respecting the rules of phenomenality and take the figure of a paradox of paradoxes, saturation of saturation, become a phenomenon of revelation.

Revelation as the fifth type of saturation, as saturation of the saturation, as the squared saturation, must contain the features of the four previous figures of saturated phenomenon. It is no longer just a paradox, but a paradox of paradoxes, which Marion describes as the paradoxotaton, the most surprising, the second degree paradox. It is not just a saturated phenomenon, but saturation of the saturation, because 'it concentrates on it alone the four types of saturated phenomena and gives itself at the same time as historical event, as idol, as corporeality and as icon (face) ${ }^{50}$. It is about the saturation of the fifth type, but not as a new term, but 'because by confusing them in itself, it saturates phenomenality in the second degree, by saturation of saturation, ${ }^{, 51}$.

\section{THE PHENOMENON OF JESUS CHRIST AS A PARADIGM OF REVELATION}

For Marion, the manifestation of Jesus Christ described in the New Testament is the paradigm of the phenomenon of revelation. Let us stress once again: it is not about stating the real manifestation of Jesus Christ, its historicity and meaning, but describing it in terms of pure possibility and reduced immanence of givenness. Describing Jesus' manifestation in this perspective, we act as phenomenologists (description of phenomenological possibility) and as philosophers (confrontation of the visible Christ with his possible conceptual role to formulate it as a paradigm). Therefore, the manifestation of Christ described in the New Testament is recognized by Marion as a paradigm of revelation - Jesus reveals himself according to the four figures of saturation we have presented above.

Firstly, the phenomenon of Christ is an event - it gives out visually as a completely unpredictable event. Christ is radically different from the prophecies that promise him. His coming is like lightning, which 'comes from the east and is seen (Gr. fainetai) as far as the west' (Mt. 24: 27), in one motion saturating what is visible. The event-like character of Christ is not something external, but his identity and is accomplished in him. He is the one who is to come or happen. As saint John the Baptist says about him: 'The one who is coming after me ranks ahead of me because he existed before me' (Jn. 1: 15); 'there is one among you whom you do not recognize, the one who is coming after me, whose sandal strap I am not worthy to untie' (Jn. 1: 26-27). His coming therefore defines him - it does not depends on Jesus, but rather Jesus depends on it. Jesus' eventuality does not come from him: 'I did not come on my own' (Jn. 8:42), but depends on the Father: 'you sent me into the world' (Jn. 17: 18). By surrendering to his unforeseen eventuality, Christ surrenders to the Father. It is also impossible to predict the end of the world, that is, the eschatological advent of Christ: 'But of the day or hour, no one knows, neither the angels in heaven, nor the Son, but only the Father' (Mk. 13: 32). It is not surprising, therefore, that the Christian's attitude is to watch: ' $\mathrm{Be}$ watchful! Be alert! You do not know when the time (Gr. kairos) will come' (Mk. 13: 33) this is a phenomenological attitude, adapted to the event character of the phenomenon of Christ. The event cannot be forecasted, predicted or anticipated - the only way to perceive the phenomenon of Jesus is to watch and wait, and therefore focus on the present and not on the future. Besides, the very time (Gr. kairos) is reversed in the phenomenon of Christ - the past comes after the present, after the event: 'The one who is coming after me ranks ahead of

${ }^{50}$ Ibidem, p. 384-385.

${ }^{51}$ Ibidem, p. 385. 
me because he existed before me' (Jn. 1: 15). Christ is an event, a completely unforeseen paradox, because the visibility in him saturates any preceding conception.

Secondly, the phenomenon of Christ is an idol - his 'content' far exceeds what a look can bear. Christ says to his disciples: 'I have much more to tell you, but you cannot bear it now' (Jn. 16: 12). What is it in Christ that we cannot bear in our regard? It is his visibility as the Son of God: 'he was transfigured before them, and his clothes became dazzling white, such as no fuller on earth could bleach them' (Mk. 9: 2-3). The white of Jesus' clothes blinds the apostles accompanying him: 'Suddenly, looking around, they no longer saw anyone but Jesus alone with them' (Mk. 9: 8). The idol fills the entire field of visibility, and the apostles' gaze froze in an excess of visibility. Also when he makes himself known as Christ, he is unbearable: 'When he said to them, "I am", they turned away and fell to the ground' (Jn. 18: 6-7). However, the most important moment showing Christ as an idol is his resurrection, which transcends what is conceivable in this world and is therefore terrifying: 'They said nothing to anyone, for they were afraid' (Mk. 16: 8). However, this fear does not lead to negation or escape, but at the same time it is a source of joy: 'They went away quickly from the tomb, fearful yet overjoyed' (Mt. 28: 8). The resurrection as a saturated phenomenon is over the touch and avoidance of touch [to Thomas: 'Put your finger...' (Jn. 20: 27); to Mary Magdalene: 'Stop holding on to me' (Jn. 20: 17)]. It is also beyond closeness and distance [two different descriptions of the ascension - in Matthew: "And behold, I am with you always, until the end of the age' (Mt. 28: 20); in Luc: 'As he blessed them he parted from them and was taken up to heaven' (Lk. 24: 51)]. Man's look at Christ is saturated with an excess of visibility.

Thirdly, Christ is a body, he is an absolute phenomenon that abolishes every relationship. He does not need any relation to reveal himself - as a saturated phenomenon he appears starting from himself. The moment of corporeal death is the moment when the truth about Him is revealed, it presents the highest form of visibility: 'Truly, this was the Son of God' (Mt. 27: 54). Jesus' corporeality is the more manifested the more it is auto-affected only a living, feeling body suffers, dies and can therefore live. Corporeality consists in the fact that one auto-affects himself, it does not need to be in any relationship. This is exactly how the phenomenon of Christ is given to us - it reveals itself on its own; it cannot be placed in one phenomenological horizon, but it requires multiplicity, which shows the end of the Gospel of Saint John: 'Now Jesus did many other signs in the presence of his disciples that are not written in this book' (Jn. 20: 30). Christ's deeds transcend the horizon of the world, they are not of this world, they require different horizons and other worlds. To say that Jesus is not from this world means that the world of the common-law phenomena is not his world. This principle of a multitude of horizons governs the Christ's body (his Kingdom is not from this world; an inscription in three languages on the cross; numerous evangelist-writers trying to testify about him; the multitude of Jesus' names).

Fourthly and lastly, Christ appears as an invisible phenomenon, i.e. an icon. It is not I that looks at him, but he is looking at me and constituting me as a witness. The icon is an inverted look, it is the Lévinas' face. In this aspect, the I constituting loses its meaning: 'No slave is greater than his master' (Jn. 15: 20). Jesus' look is first and forewarning. Christ himself chooses disciples, calls whomever he wants, appoints apostles, changes their names, sends them as witnesses. This is perfectly illustrated by the text about a rich young man who asks him about eternal life, i.e. access to the phenomenon par excellence. Jesus gives the conditions and the young man completely adapts to these criteria, so he submits to the gaze of Jesus, he sees himself through his eyes: 'Teacher, all of these I have observed from my 
youth' (Mk. 10: 20). And at this moment Jesus reveals his iconic character: 'Jesus, looking at him, loved him and said to him' (Mk. 10: 21). It is not about merely directing the eye, but about radically establishing what it is looking at. The gaze sees the other, recognizes him, establishes and individualizes him. But it also intensifies the saturation.

Starting from the saturation of the second degree of the phenomenon of Christ, we see that God cannot be conceived metaphysically, as a concept, cause or reason sufficient ${ }^{52}$. God reveals himself and fits in with phenomenality, thoroughly saturating it. And the other way: if we want to know God, it is only according to God, and his way of understanding is not metaphysics, but revelation. In it God gives himself on his own, precedes us, calls us, saturates the horizon of manifestation, dazzles the look, for first of all he is the anticipating love. So God reveals himself as Love ${ }^{53}$ and God's way is radical and redundant revelation as radical and excessive Love. Husserl took God's transcendence in brackets. Marion, on the other hand, does not suppose the presence of God, but introduces into phenomenology the very possibility of revelation. The latter, however, does not violate the reduction, because revelation as a possibility takes place in the very immanence of the phenomenon. Marion recognizes God's right to be phenomenal and there is no danger of theologizing of phenomenology here.

\section{DIALECTIC OF THE SACRAMENT AND THE PREACHING}

In the light of Marion's findings, Ricoeur's alternative between revelation and proclamation seems exaggerated and too idealized. Ricoeur emphasized the non-verbal nature of the revelation and the hermeneutic character of the proclamation. However, shouldn't these two domains be somehow connected or at least mediated? It is important that the religious phenomenon is given to us as a saturated phenomenon. It reveals itself as such and on its own initiative, on its own terms, which means that it can be given both in the sacral and verbal sphere. It seems that religious studies have led Ricoeur to a certain impasse, which he is also aware of. That is why he tries to cross the bridge between the sacral discourse and the discourse of the word ${ }^{54}$.

Ricoeur distinguishes between two types of saying: an 'rebellious utterance' and a 'statement of secondary listening, ${ }^{55}$. Rebellious speech emphasizes the impossibility of reconciliation between the sacrum and the word, and maintains that kerygmatic religion is anti-sacral $^{56}$. He bases his position on three theses. Firstly, our world is de-sacralized and devoid of the sacrum, so the deity no longer manifests itself in it. It is a secular, scientific and technical world, which was emphasized among others in Heidegger ${ }^{57}$. Secondly, even if we encounter some elements of the sacrum in the industrialized world, it is a rudimentary, replacement sacrum, withdrawn to surrogate myths and perverted rites, or to the subconscious and as such deserves no survival. Thirdly, given that the sacrum is removed, the only form of religion in the modern world can only be one that can be heard. Despite the dominant culture of the image, not the word, only the religion of the word, kerygmatic, which needs to be cleared of the sacral envelope can survive.

\footnotetext{
${ }^{52}$ Jean-Luc Marion, Dieu sans l'être, Fayard, Paris, 1982, p. 51.

${ }^{53}$ Ibidem, p. 123.

${ }^{54}$ Paul Ricoeur, Manifestation et proclamation, p. 71.

55 Ibidem, p. 69.

56 Ibidem, p. 71.

${ }^{57}$ Philippe Huneman, Estelle Kulich, Introduction à la phénoménologie, p. 73-74.
} 
Ricoeur finds the rebellious discourse too one-sided. The cult of science and technology is, in his opinion, ideological in nature, and there is nothing to rush to treat the sacrum as something archaic. Even if it occurs in a rudimentary and degenerated form, it, together with scientific and technical ideology, is a testimony to modern nihilism. It is only when analyzing the modern spirit that one comes to the conclusion that human is not possible without sanctity ${ }^{58}$. It is impossible to completely de-sacralize the world or human life in it. Admittedly, the word religion opposes the numinosum, but only insofar as it assumes its functions. An important conclusion follows: the word, which informs and calls man in various forms, must also become a place of revelation. Ricoeur, therefore, postulates the reconciliation of word and revelation, as in the Christian tradition there is a bond between the sacrament and preaching.

Reconciliation, and even identification of the word and revelation, takes place in Jesus Christ - here Ricoeur and Marion's paths converge. Prologue to the Gospel of St. John: 'And the Word became flesh and made his dwelling among us' (Jn. 1: 14), certifies it. Ricoeur also recalls Hegel, for whom Christ is the 'absolute appearance ${ }^{59}$, which he places in extension of archaic hierophanies. Cosmic symbolism was not rejected in Christianity but reinterpreted according to the requirements of the proclamation. God has supra-uranic qualities: he is the highest, he is the sovereign of the hosts of heaven, his glory is similar to sunlight. Cosmic symbolism is not dying, but is being transformed while being at the service of the kerygma: victory over the power of waters and chaos is to overcome evil, New Zion overthrows the holy city, the Messiah overthrows the temporal king, and Golgota becomes the axis mundi. These transformations are possible by the work of the word, and the bond between the word and the cosmos turns out to be dialectical ${ }^{60}$. Therefore, one should not strip the word from the rite, from the sacrum, because it will then lose its revealing power and will only be reduced to ethical instruction. In Christianity, this is a reconciliation between the sacrament and preaching. In the sacrament, the symbolism prevails, while the kerygmatic, apologetic and instructive element comes to the fore in preaching. However, both are important because only then can revelation be made in the word. A word without the support of the cosmic sacrum would become too abstract and sophisticated, and yet the point is that it speaks to both reason and will, that is to the whole human being.

\section{THEOLOGY AS THE HERMENEUTICS OF THE EUCHARIST}

However, this Ricoeurian concept of reconciliation of the word and the rite should be clarified from the phenomenological point of view. We already know how revelation is carried out, what it is about and how its possibility is based. According to Marion, the place of reconciliation of the word and the rite is the Eucharist, which, however, requires proper hermeneutics. It is in it that God speaks fully, making revelation, and thus enabling theology itself.

The event of Jesus Christ is at the center of Christian theology. It follows that theology has no its own subject, it rather attempts to give access to the event. Theology uses the texts of the Holy Scriptures, but it does not transmit the text, but the event through the text. What is the relationship between a text and an event? The event is original and the text flows from it ${ }^{61}$. Is it possible to return to the event through a text? Certainly, the theology of

\footnotetext{
${ }^{58}$ Paul Ricoeur, Manifestation et proclamation, p. 73.

${ }^{59}$ Ibidem, p. 75.

${ }^{60}$ Ibidem.

${ }^{61}$ Jean-Luc Marion, Dieu sans l'être, p. 204.
} 
the event of Jesus Christ cannot be the so-called scientific exegesis of the Holy Bible, which reads the text starting from it. It subjugates a text that would like to talk about something else that lies beyond it, which is more original - the event is just that. Meanwhile, in Christianity, the text does not create an event, but the event of Jesus Christ, especially his death and resurrection, is absolutely the first, is the Word in which God expresses himself. The text was edited after the event and is secondary to it.

The texts themselves cannot reconstruct the event. This is extremely important in theology, because it proves that the Passion of Jesus was really an event, and not a product of a text or human interpretation. On the other hand, only a complete repetition of this event opens for us the texts that we begin to understand. You can see here not only the essence of theology, but also its difference from other sciences and arts. All other sciences, including literature, accept the lack of access to an event that is lost in the darkness of the past. Only theology claims to speak about something alive and present ${ }^{62}$. It would not have this feature if its source and primacy was the text. Meanwhile, the theological discourse stems from the event, not from the text. Moreover, theology proclaims the constant repetition of this event, which means that it does not close in the past but happens all the time. Therefore, the fundamental question for theology arises: how to find access to this event? Is such hermeneutics of the text possible that would not only explain its sense, but above all realize a real event?

According to Marion, two hermeneutics are possible: hermeneutics of sense and hermeneutics of the event. The first hermeneutics involves interpreting the text, and the second one gives access to the event. Their clash is apparent in the story of the disciples on the road to Emmaus (Lk. 24). The first of the hermeneutics is represented by the disciples, the second by Jesus. We learn that the Passion of Jesus took place in Jerusalem - so it is already a past event ('You are the only one (...) who does not know of the things that have taken place there in these days', Lk. 24: 18). Only the words about the event remain, in this case rumours and gossip ('What are you discussing as you walk along?'; Lk. 24: 17). However, the text does not give an access to the event. When the disciples comment on an event using their human words, they create certain hermeneutics, but it is able to convey only a certain sense, not the event itself ('But their eyes were prevented from recognizing him'; Lk. 24: 16). It is completely different from the perspective of Jesus and his hermeneutics, in which the referent means itself and speaks of itself ('Jesus himself drew near and walked with them'; Lk. 24: 15). What's more, he begins to interpret himself ('Oh, how foolish you are! How slow of heart to believe all that the prophets spoke! Was it not necessary that the Messiah should suffer these things and enter into his glory? Then beginning with Moses and all the prophets, he interpreted to them what referred to him in all the scriptures'; Lk. 24: 2527). The Paschal event is read in the text, but not the text and its sense is the purpose here. Besides, Jesus appears as the 'only one who does not know' what everyone knows. No text is able to express the referent, but it is the referent that can explain the text, and by such explaining it explains itself with the help of the text. Jesus is here both speaking and spoken at the same time - in this way he speaks himself ${ }^{63}$.

In such manner Marion reveals the primary task of a theologian. The basis of theological work is the hermeneutics of the biblical text, but another type of it, i.e. hermeneutics which is not intended to reveal the sense of the text, but through the text to

${ }^{62}$ Ibidem, p. 206.

${ }^{63}$ Ibidem, p. 208. 
reveal the event. However, only the Word can do this - only it can adequately speak about this which 'refers to him in all the scriptures'. In the hermeneutics of Jesus, the Word goes beyond the text and reaches the referent itself. The fundamental principle of theology is not, therefore, any reading of the text and commenting on it, but reaching its referent. More precisely, let the Word read the text from its point of view. As Marion writes: 'The theologian must penetrate through the text up to the Word, interpreting it from the Word's point of view, ${ }^{64}$.

So it is not the theologian who makes the exegesis of Scripture, but the Word personally performs the hermeneutics of words. Nevertheless, this hermeneutics does not lead to understanding and sense, but strives for one thing - to make it visible. In this passage (Lk. 24), Jesus explains the Scriptures to his disciples, but this hermeneutics is only a preview of the absolute hermeneutics, which follows later in the pericope. It is the Eucharistic moment - it is in it that Jesus is recognized. On their road to Emmaus, the disciples heard an explanation of the Scriptures (Word explaining the word) and then they invited Jesus to supper. After breaking of the bread, they recognized him and 'their eyes were opened' (Lk. 24: 31). The Eucharist not only completes the hermeneutics of the Word, but also becomes the absolute hermeneutics. It penetrates through the text, up to the referent ${ }^{65}$.

Why is the Eucharist the absolute hermeneutics? For in it the Word speaks the unspeakable words addressed to the Father: 'he took bread, said the blessing, broke it, and gave it to them' (Lk. 24: 30). This leads to an extremely important conclusion: theology has its proper place not in the Scriptures but in the Eucharist. Or, to be more precise, the Scriptures and the Eucharist should not be contrasted as separate fields - the Eucharist also includes the Word of God - but it is only in the Eucharist that hermeneutics find its place. In the Eucharist the Word not only interprets itself, but turns to the Father and devotes himself to him by speaking the ineffable word of God - the purpose of all theology. So we can formulate the fundamental principles of such theology. The theologian cannot stop at the sense of the text, even the most sublime and spiritual, but he should penetrate through the text up to the Word and interpret it from the Word's point of view. This means that it is not the theologian who speaks, he only lets the Word to speak itself. The only place where the Word speaks personally is the Eucharist. In the Eucharist, the Word speaks silently, which makes theology paradoxical.

The principle of the Eucharist is that at the time of recognition Jesus disappears: 'With that their eyes were opened and they recognized him, but he vanished from their sight' (Lk. 24: 31). The purpose of the Eucharist was to make it visible, while Jesus disappears. It is explained in The Gospel of St. John, where Jesus says: 'It is better for you that I go' (Jn. 16: 7). These words herald the outpouring of the Holy Spirit. The disappearance of Jesus, his invisibility is a preview of the Holy Spirit's work. The Word recognized in the Eucharist disappears, but unlike a disappearing object. The Word disappears so as not to fix on itself, but by receiving the Body and Blood, it lives in the disciples. They can recognize this new presence only in the Spirit. In the Eucharist, it is the disciples who take place of the Word, become it, it incarnates in them. Now they are to return to Jerusalem and proclaim the hermeneutics of the Eucharist: 'Then the two recounted what had taken place on the way and how he was made known to them in the breaking of the bread' (Lk. 24: 35). In this sentence there is the Greek word exegounto - they recounted, i.e. they made exegesis. At the same

${ }^{64}$ Ibidem, p. 210.

${ }^{65}$ Ibidem, p. 212. 
time, it is a making presence narrative: 'While they were still speaking about this, he stood in their midst' (Lk. 24: 36). Jesus gives his disciples the Spirit and again says: 'That it is I myself' (Lk. 24: 39). The hermeneutical circle closes: first the text, then the Word that speaks itself, at the moment of understanding and recognition the Word disappears, but only to incarnate in the disciples and give a new presence.

Since theology has its seat in the Eucharist, it means that it is not so much proclaimed, written down or practiced as science is, but, first of all, it is celebrated. Theology is nothing but the hermeneutics of the text, which takes place in community through the theologian's ministry ${ }^{66}$. Marion clearly emphasizes the three essential elements of theology. The first is the hermeneutics of the text - in the liturgical assembly the texts of the Old and New Testaments are read, and then the priest presiding at the Eucharist explains them. The community demands that this explanation help understand not the word but the Word. At this stage, however, the Word is not yet recognized, which shows us that theology should not stop at the level of discourse. Word recognition is done in the breaking of the bread. In the Eucharist the Word makes the priest his person (lat. in persona Christi) and incarnates in those who receive it. The community matures, that is it becomes more itself with the deepened Eucharistic life, the more it calls and receives the Word.

\section{CONCLUSIONS. THE PHENOMENON NEEDS HERMENEUTICS}

It could seem that Ricoeur continues the idea of separation between phenomenology and hermeneutics, which J. Grondin was talking about ${ }^{67}$. In this approach, phenomenology seeks to establish a certain cognitive foundation and does without words, while hermeneutics does not exist without textual and linguistic structures and does not deal with the possibility, but with content. However, after looking at the studies of the revelation in both Ricoeur and Marion, we come to the conclusion that this idea should be rejected. In work De surcroit Marion writes: 'the interpretation of the phenomenon as given not only does not prohibit hermeneutics, but requires it ${ }^{68}$. While after Heidegger no one questions the need for hermeneutics, one should look at its phenomenological legitimacy ${ }^{69}$. The analysis contained in this text satisfy this postulate.

Let's collect the results of our research. We have dealt with the problem of revelation as a key topic for both phenomenology and hermeneutics, but while the first discipline examines the possibility of revelation, the second attempts to report its content. Ricoeur, following the hermeneutic path, initially introduced a radical separation between revelation, which is non-verbal directly and does not need hermeneutics, and proclamation as a message of religions related to the word: Judaism, Christianity and Islam. However, in the course of his analysis, he decided that the separation of these two orders lost something extremely valuable, and therefore requires some mediation. That connection between the sacrum and proclamation is the word, especially in the rite or sacramental situation. It then becomes a place of revelation.

${ }^{66}$ Ibidem, p. 214.

${ }^{67}$ Jean Grondin, "Les tensions dans la pensée de la donation ultime de Jean-Luc Marion”, in Dialogue 38 (1999), p. 559.

68 Jean-Luc Marion, De surcroît. Études sur les phénomènes saturés, PUF, Paris, 2001, p. 41.

${ }^{69}$ Paul Marinescu, "L'universalité et les « sans fin » de l'herméneutique : Jean-Luc Marion, lecteur de Ricoeur", in C. Ciocan and A. Vasiliu (eds.), Lectures de Jean-Luc Marion, Cerf, Paris, 2016, p. 343. 
The juxtaposition of Ricoeur's thoughts with Marion's phenomenology brings valuable complementation in two areas. First of all, it says how revelation is possible, i.e. how it is possible for something to appear, come into the condition of a phenomenon and be given on its own initiative and on its own terms. The revelation comes in the form of a saturated phenomenon that surprises the recipient with an excess of visibility. But also, secondly, Marion clarifies Ricoeur's demand for reconciliation of the sacrament and preaching. It takes place in the Eucharist, which demands special hermeneutics. Marion's hermeneutics of the Eucharist is part of his reflection on God in opposition to ontotheological theories.

Thanks to Ricoeur and Marion's two-voice on revelation, we can look at the relationship between phenomenology and hermeneutics. It should be assumed that both areas need each other. First, the phenomenon, especially defined as saturated, demands hermeneutics. This is due to the fact that it appears to be paradoxical and impossible, thus the very impossibility is assimilated to human experience. Marion describes such hermeneutics as 'without end' (sans fin $)^{70}$. But also the hermeneutics of revelation calls for phenomenological validation as rooting in human experience. What connects both perspectives in the project of hermeneutic phenomenology is the idea that the subject is not a starting point, but an arrival point - it is what is the last in philosophical cognition. We understand ourselves in result of many cognitive acts and interpretation processes. The phenomenon of revelation is released from the subject in the sense that it is not created by the subject, but appears on its own initiative. On the other hand, by learning about phenomena, the subject gets itself in a 'long way of self-understanding'.

Ricoeur in the essay Phénoménologie et herméneutique: en venant de Husserl... indicates that there is a need for cooperation between the two domains, which he also describes as dialectic ${ }^{71}$. In his opinion, hermeneutics develops on the basis of phenomenology, and phenomenology needs some hermeneutic assumptions. The description of reality is and must be an interpretation and in this sense there is no limit, it cannot be enclosed in any system. We have found this out by exploring the phenomenon of revelation.

\section{BIBLIOGRAPHY:}

[1] BENOIST Jocelyn, L'idée de la phénoménologie, Beauchesne, Paris, 2001.

[2] BUBER Martin, I and Thou, Scribner, New York, 1958.

[3] CORBIN Henry, L'imagination creatrice dans le soufisme d'Ibn' 'Arabi, Flammarion, Paris, 1961.

[4] DASTUR Françoise, "De la phénoménologie transcendentale à la phénoménologie herméneutique", in: J. Greisch and R. Kearney (eds.), Paul Ricoeur. Les metamorphoses de la raison herméneutique. Actes du colloque de Cerisy-la-Salle, 1-11 août 1988, Cerf, Paris. 1991, pp. 37-50.

[5] DEI VERBUM. Dogmatic Constitution on Divine Revelation of the Second Vatican Council, in:http://www.vatican.va/archive/hist_councils/ii_vatican_council/documents/vatii_const_19651118_deiverbum_en.html [10.06.2020].

[6] GRONDIN Jean, "Les tensions dans la pensée de la donation ultime de Jean-Luc Marion", in: Dialogue 38 (1999), pp. 547-559.

[7] GRONDIN Jean, Paul Ricoeur, PUF, Paris, 2013.

[8] HEIDEGGER Martin, Sein und Zeit, Niemeyer, Tübingen, 1960.

[9] HENRY Michel, Incarnation. Une philosophie de la chaire, Seuil, Paris, 2000.

[10] HUNEMAN Philippe, KULICH Estelle, Introduction à la phénoménologie, Armand Colin, Paris, 1997.

${ }^{70}$ Jean-Luc Marion, De surcroît, p. 39.

${ }^{71}$ Paul Ricoeur, Du texte à l'action. Essais d'herméneutique II, Seuil, Paris, 1986, pp. 39-73. 
[11] HUSSERL Edmund, Logische Untersuchungen, Bd. 1-2, Max Niemeyer Verlag, Halle, 1913.

[12] JANICAUD Dominique, Le tournant théologique de la phénoménologie française, Éditions de l'éclat, Combas, 1991.

[13] JASPERS Karl, Allgemeine Psychopathologie, Springer, Berlin-Heidelberg, 1946.

[14] JASPERS Karl, Psychologie der Weltaschaungen, Springer, Berlin-Heidelberg-New York, 1971.

[15] JERVOLINO Dominique, Paul Ricoeur. Une herméneutique de la condition humaine, Ellipses, Paris, 2002.

[16] MARINESCU Paul, "L'universalité et les « sans fin » de l'herméneutique: Jean-Luc Marion, lecteur de Ricoeur", in: C. Ciocan and A. Vasiliu (eds.), Lectures de Jean-Luc Marion, Cerf, Paris, 2016, pp. 339-349.

[17] MARION Jean-Luc, De surcroît. Études sur les phénomènes saturés, PUF, Paris, 2001.

[18] MARION Jean-Luc, Dieu sans l'être, Fayard, Paris, 1982.

[19] MARION Jean-Luc, Étant donné. Essai d'une phénoménologie de la donation, PUF, Paris, 1997.

[20] MARION Jean-Luc, "La « fin de la métaphysique » comme possibilité", in: Y.-Ch. Zarka and B. Pinchard (eds.), Y a-t-il une histoire de la métaphysique?, PUF, Paris, 2005, pp. 343-368.

[21] MARION Jean-Luc, La rigueur des choses. Entretiens avec Dan Arbib, Flammarion, Paris, 2012.

[22] MARION Jean-Luc, "Le phénomène saturé", in: M. Henry, P. Ricoeur, J.-L. Marion, J.-L. Chrétien, Phénoménologie et Théologie, Criterion, Paris, 1992, pp. 79-128.

[23] MARION Jean-Luc, L'Idole et la distance, Grasset, Paris, 1977.

[24] MARION Jean-Luc, Prolégomènes à la charité, Éditions de la Différence, Paris, 1986.

[25] MARION Jean-Luc, Réduction et donation. Recherches sur Husserl, Heidegger et la phénoménologie, PUF, Paris, 1989.

[26] MARION Jean-Luc, Sur la théologie blanche de Descartes. Analogie, création des vérités éternelles, fondement, PUF, Paris, 1981.

[27] MARION Jean-Luc, Sur le prisme métaphysique de Descartes. Constitution et limites de l'ontothéo-logie cartésienne, PUF, Paris, 1986.

[28] MARION Jean-Luc, Sur l'ontologie grise de Descartes. Science cartésienne et savoir aristotélicien dans les Regulae, Vrin, Paris, 1975.

[29] NICHOLSON Graeme, "Hermenutical Phenomenology", in: L. Embree (ed.), Encyclopedia of Phenomenology, Kluwer Academic Publishers, Dordrecht, 1997, pp. 304-308.

[30] RAD Gerhard von, Theologie des Alten Testaments, Kaiser Verlag, Munich, 1957.

[31] RICOEUR Paul, De l'interprétation. Essai sur Freud, Seuil, Paris, 1965.

[32] RICOEUR Paul, Du texte à l'action. Essais d'herméneutique II, Seuil, Paris, 1986.

[33] RICOEUR Paul, La métaphore vive, Seuil, Paris, 1975.

[34] RICOEUR Paul, Le conflit des interprétations: Essais d'herméneutique, Seuil, Paris, 1969.

[35] RICOEUR Paul, "Lectio magistralis", in: D. Jervolino, Paul Ricoeur. Une herméneutique de la condition humaine, Ellipses, Paris, 2002, pp. 75-91.

[36] RICOEUR Paul, "Manifestation et proclamation", in: E. Castelli (ed.), Le sacré: études et recherches: actes du $14^{e}$ Colloque international sur la thématique de la démythisation, Rome, 4-9 janvier 1974, organisé par le Centre international d'études humanistes et par l'Institut d'études philosophiques de Rome, Aubier, Paris, 1974, pp. 57-76.

[37] RICOEUR Paul, Philosophie de la volonté. Tome 1. Le volontaire et l'involontaire, Aubier, Paris, 1950.

[38] RICOEUR Paul, Philosophie de la volonté. Tome 2. Finitude et culpabilité, Aubier, Paris, 1960.

[39] RICOEUR Paul, Soi-même comme un autre, Seuil, Paris, 1990.

[40] RICOEUR Paul, Temps et récit. Tome 1. L'intrigue et le récit historique, Seuil, Paris, 1983.

[41] RICOEUR Paul, Temps et récit. Tome 2. La configuration dans le récit de fiction, Seuil, Paris, 1984.

[42] RICOEUR Paul, Temps et récit. Tome 3. Le temps raconté, Seuil, Paris, 1985.

[43] ROMANOWSKA-ŁAKOMY Halina, Our Sacred Dimension. The Sanctity of the Common Man, Cambridge Scholars Publishing, Cambridge, 2016.

[44] SCHELER Max, Vom Ewigen in Menschen, Francke Verlag, Bern-München, 1954.

[45] SCHOLTZ Günther, "Was ist und seit wann gibt es »hermeneutische Philosophie«?", in: DiltheyJahrbuch für Philosophie und Geschichte der Geisteswissenschaften Vol. 8 (1993), pp. 93-119.

[46] SCOTT-BAUMANN Alison, Ricoeur and the Hermeneutics of Suspicion, Continuum, London-New York, 2009.

[47] STEVENS Bernard, "En guise d'introduction: L'évolution de la pensée de Ricoeur au fil de son explication avec Husserl", in: Études phénoménologiques 11 (1990), pp. 9-27. 
[48] TABET Pascale, Amour et donation chez Jean-Luc Marion. Une phénoménologie de l'excès, L'Harmattan, Paris, 2017.

[49] TILLICH Paul, Dynamics of faith, Harper \& Row, New York, 1957.

[50] VINOLO Stéphane, Dieu n'a que faire de l'être. Introduction à l'œuvre de Jean-Luc Marion, Germina, Paris, 2012. 